\title{
The facts about Stemedica
}

\section{To the Editor:}

The News Feature in the September issue by Jane Qiu ${ }^{1}$ entitled “Trading on Hope" highlights the lack of oversight in certain clinical centers now offering stem cell treatments. At Stemedica, we recognize and respect the role that research and approved clinical trials have in the advancement of the stem cell industry. However, as vice chairman \& CEO of the company, I was extremely concerned to find references within Qiu's article about our company. These references are inaccurate and potentially damaging to Stemedica's image within the regulatory, medical and investment communities and need to be corrected.

On p. 791 of the article, Qiu included Stemedica as one of the organizations in Table 1 "promoting unproven stem cell treatments." This is incorrect: Stemedica does not promote unproven stem cells treatments.

Later, on the same page, Qiu references two basic bench researchers-Sorapop Kiatpongsan of the University of Bangkok and Douglas Sipp of the Riken Center for Developmental Biology in Kobe, Japan. Until a recent effort by Stemedica to engage these two researchers, neither had ever had direct contact with anyone at Stemedica. Had they visited our facilities or interviewed any of our personnel, they would have learned the facts about our position regarding the evolution of stem cell therapy and the importance we place in having such therapy conducted under strict clinical protocols and with full regulatory approval.

I would also like to state that neither Qiu nor anyone else from Nature Biotechnology called Stemedica to confirm the facts or verify that the information in the article concerning Stemedica was accurate.

Although Stemedica commends Qiu's attempt at disclosing misuses of stem cell treatment, we regret that inaccurate information was advanced about our company in the article. Interested readers are invited to visit our web site (http:// www.stemedica.com/) to review articles and press releases on research, conference presentations and other information about Stemedica. We strive to do what is right and responsible and take exception to any inaccurate information about our company.

Maynard A Howe

Stemedica Cell Technologies, Inc., San Diego, California, USA. e-mail:mhowe@stemedica.com

COMPETING INTERESTS STATEMENT

The author declares competing financial interests: details accompany the full-text HTML version of the paper at http://www.nature.com/ naturebiotechnology/.

1. Qiu, J. Nat. Biotechnol. 27, 790-792 (2009).

\section{Nature Biotechnology replies:}

The current version of Stemedica's website (http://www.stemedica.com/) neither publicizes treatments in stem cell clinics nor promotes them. In the process of fact checking the Qiu article, Nature Biotechnology editors twice checked the
Stemedica website in June and August. When the website was checked on June 24,2009 , wording was present on the website indicating that the company was still publicizing treatments in stem cell clinics at that time. A subsequent check of the website on August 24 was unsuccessful as the website was not working. Evidence from the Internet Archive-as recent as 2008-does indicate that Stemedica publicized treatments in the past on its website (http://web.archive.org/ web/20080222212144/www.stemedica.com/ treatmentcenters/; http://web.archive.org/ web/20071008142206/www.stemedica.com/ patients/application/).

\section{Biotech and gender issues in the developing world}

\section{To the Editor:}

The recent World Food Prize Symposium ${ }^{1}$ celebrated the life of Norman Borlaug and the work of laureate sorghum breeder Gebisa Ejeta. The star-studded cast of speakers was led by Bill Gates and included women CEOs of major multinational corporations. Gates described how his foundation came to the realization that to deal with issues of health there must be good food in the stomach and described their emphasis on dealing with agricultural issues of nutrition, drought, insects and diseases with a clear and resounding emphasis on biotech, where it could be helpful. Gates and many others addressed gender issues, with the emphasis on girls' education and health so that the best might enter the business world and academia.

Unfortunately, very little was said about the vast majority of women, who, no matter how well educated, would return to their rural settings, relegated to mainly 'femanual' work: soil preparation, planting, weeding and more weeding. Not a single invited speaker (except the laureate) mentioned weeds, let alone how modern technology can help. Engineers have provided designs

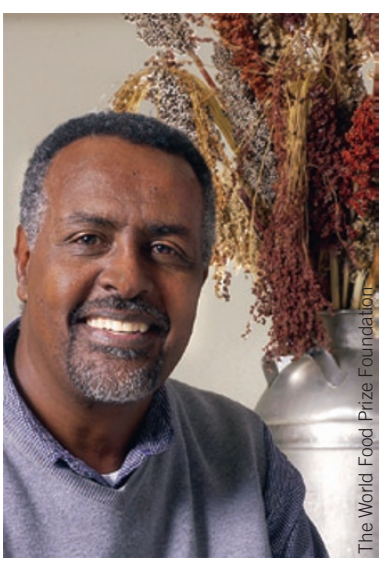

Purdue University researcher Gebisa Ejeta received the World Food Prize in October for his work on breeding witchweedresistant sorghum. for more ergonomic hoes. Genetic engineers can do better. Already transgenic glyphosate-resistant maize has become a hit among women farming in South Africa, who can now spray down more weeds in a day than they could hoe in a backbreaking month.

Weed control biotech is not limited to herbicideresistant crops. Ejeta received the prize for his work intelligently combining genes that partially encode resistance to various stages of attack by the root-parasitic weed Striga (witchweed). It is not easy to transfer these 3 or 4 recessive genes scattered throughout the sorghum genome from locally adapted variety to variety by backcross breeding, even with marker-assisted selection. When the genes are finally isolated, they can be put in a single dominant cassette that could be engineered into one variety of sorghum and, one hopes, other Striga-susceptible crop species and easily backcrossed to any local variety, preserving crop biodiversity. 